\title{
IN MEMORIAM \\ MARC GEOFFROY (1965-2018)
}

\author{
JULES JANSSENS \\ UNIVERSITY OF LEUVEN
}

On 23 April Marc Geoffroy passed away at the age of only 52. I knew him personally very well. For almost twenty years we had intensively worked together on several projects in a spirit of profound mutual respect. But there was so much more than a common scientific interest and collaboration. We were not just colleagues, but friends in the real sense of the word. I therefore will not just remember him as a brilliant, erudite scholar, who helped me a lot in improving my own scientific research, but also as a warm human being who was generous in so many respects.

If one looks at Marc's scholarly works, one sees easily the scholar who embodies the ideal of what is one of the main purposes of the present journal. When one consults the website, one reads: "Mediterranea is an international journal focusing on various areas of knowledge transfer from Late Antiquity to the Early Modern period, covering the Middle East and the Mediterranean basin, and paying special attention to philological, philosophical, scientific, cultural and religious fields of research ».

Looking at the last of these purposes, i.e. the fields of research specified, there is no doubt that Marc combined in his works at least two of them, and this in a unique way, namely philology and philosophy. This is evidenced in his translations of texts (mainly, although not exclusively, Arabic) as well as in the edition of Avicenna's commentary on book Lambda, 6-10, which he made together with Meryem Sebti and myself, and of fragments of an Arabic version (written in Hebrew characters) of Averroes's Great Commentary on the De Anima he made together with Colette Sirat which will been published at the beginning of this year, but of which a first preliminary study was already published in $2005 .{ }^{1}$

1 Averroes, le livre du discours décisif, trans. and annot. Marc Geoffroy, introd. Alain de Libera, Flammarion, Paris 1996; AverRoEs, L'Islam et la raison. Anthologie de textes juridiques, théologiques et 
Certainly, regarding the editions, there was a collaboration, but I am sure that both Sirat and Sebti will agree with me that Marc had an exceptional knowledge of the Arabic language - after all he possessed an agrégation de langue arabe - , as well as a broad philosophical culture. Besides Arabic, he possessed as well a more than basic knowledge of Hebrew and Latin, as shown by his French translation of two epistles of Averroes on the Intellect (lost in Arabic), based on the edition of their Hebrew translation in parallel with that of the Latin work Tractatus Averoys De perfectione naturali secundum menti philosophi (and, whenever relevant, with variant passages in the closely related, perhaps better known, De beatudine animae). ${ }^{2}$ He also had a solid knowledge of ancient Greek, as shown in his paper on the influence of the Arabic translation of Alexander of Aphrodisias's De intellectu on al-Fārābỉs theory of the four intellects. ${ }^{3}$ His translations, from whatever language they originate, reveal clearly an explicit will to arrive at a sensible translation, but always with the highest respect for the basic philological rules, an attitude that also prevails in the editorial works in which he participated actively. ${ }^{4}$ So, philosophy and philology are both substantial parts of his research. But the religious issue plays an important part in his first research on Averroes. There he mainly deals with two 'religious' works of the great Andalusian scholar, i.e. Decisive treatise (Fașl al-maqāl) and Uncovering the methods of proofs with respect to the beliefs of the religious community (Kashf'an manāhij al-adilla fì

polémiques, trad. Marc Geoffroy, pref. Alain de Libera, GF, Paris 2000; Avicenna (IBN Sīnā), Commentaire sur le Livre 'Lambda' de la 'Métaphysique' d'Aristote (chapitres 6-10), ed., trans. and annot. Marc Geoffroy, Jules Janssens, Meryem Sebti, Vrin, Paris 2014 (Études musulmanes, 43); Colette Sirat, Marc Geoffroy, L'original arabe du Grand Commentaire d'Averroès au 'De anima' d'Aristote. Prémices de l'édition, Vrin, Paris 2005 (in a recent mail Sirat informed me that the final edition will be available in February 2019).

2 Averroes, La béatitude de l'âme, ed. and trad. Marc Geoffroy, Carlos Steel, Vrin, Paris 2001. It is worthwhile to note that Marc, when dealing with the fragments of al-Fārābī's Pollitical Regime, also known as Principles of Being, that are included near the end of the Latin work, compares the Latin not only with its Hebrew translation by Ibn Tibbon, on which the Latin was based, but also with the original Arabic text.

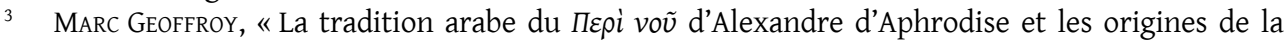
théorie farabienne des quatre degrés de l'intellect », in CRISTINA D'AnConA, GiusePPe SERRA (eds.), Aristotele e Alessandro di Afrodisia nella tradizione araba, Il Poligrafo, Padova 2002 (Subsidia Mediaevalia Patavina, 3), p. 191-231, esp. p. 206-222.

${ }_{4}$ Since I had the privilege to work with him (and Sebti) to the edition and French annotated translation of Avicenna's commentary on Lambda (see fn. 1), and to prepare (with Sebti and Michael Chase) a critical edition and annotated French translation of the same author's commentary on the Theology (a work in progress when he died, but, unfortunately, far from being finished), I was a privileged witness of the extraordinary way in which he tried to combine philosophical understanding and philological rigour. However, it was on the occasion of a last systematic revision of my edition of AvicENNA LATINUs. Liber primus naturalium: Tractatus tertius; De his quae habent naturalia ex hoc quod habent quantitatem. Académie royale de Belgique, Bruxelles 2017, that I particularly experienced how demanding he was in this respect (and at the same how justified he was in defending this ideal). 
'aqā'id al-milla), the former of which he qualifies as 'juridical', insofar as it places itself on the level of the Islamic law, while he does not hesitate to identify the latter as a treatise of kalām, 'Islamic theology'. ${ }^{5}$ In several papers, he insists on the impact of Ibn Tümart's profession of faith on the Kashf, and how Averroes tries to provide the Almohad rulers with a theological alternative for the Ash'arite kalām. ${ }^{6}$ Finally, a significant part of his research consisted in codicological description of manuscripts, as well as teaching codicology to colleagues and students. ${ }^{7}$ Now, codicology is defined in the Merriam-Webster dictionary as « the study of manuscripts as cultural (my emphasis) artefacts for historical purposes ». Hence, I think that it is not exaggerated to say that he busied himself with what one may label 'a cultural field of research'. In sum, his research encompassed extensively two of the four fields specified in the basic outline of the purposes of the journal, and, be it in a somewhat more limited way, even two additional ones.

But Marc's work was also highly in line with the second specification, i.e. " covering the Middle East and the Mediterranean basin». In the framework of two ERC-projects - one directed by Cristina d'Ancona, "Greek into Arabic. Philosophical Concepts and Linguistic Bridges ", and another by Maroun Aouad, " Philosophy in Context: Arabic and Syriac Manuscripts in the Mediterranean »-, he visited libraries and scientific institutions in many countries that are part of the concerned area, such as Turkey and Lebanon. His search for manuscripts even brought him to Timbuktu. As to the main authors on whom his studies focused, they cover a large part of that area. Averroes (Ibn Rushd), who occupies a major place in his research, was living in Muslim Andalusia, but Ibn Tūmart, indicated by Marc as one of his major sources of inspiration, was a Moroccan. Also Avempace (Ibn Bājja), who constitutes, as shown by Marc, a major source for Averroes's doctrine of intellect, was originally from Muslim Spain, but lived in his later life not only in Spain, but also in the Maghreb, more particularly in the cities of Oran and Fes (where he died). ${ }^{8}$ Al-Fārābī, discussed in the framework of

See AVERROES, L'Islam et la raison, p. 79 and p. 96.

See e.g. MARc Geoffroy, « L'Almohadisme théologique d'Averroès (Ibn Rušd) », Archives d'Histoire Doctrinale et Littéraire du Moyen Age, 66 (1999), p. 9-47; ID., « Ibn Rušd et la théologie almohadiste: Une version inconnue du Kitāb al-Kašf 'an manāhiğ al-adilla dans deux manuscrits d'Istanbul », in Medioevo, 26 (2001), p. 329-356; ID., " A propos de l'almohadisme théologique d'Averroès: L'anthropomorphisme (tağsìm) dans la seconde version du Kitāb al-Kašf 'an manāhiğ al-adilla », in Patrice Cressier, María Isabel Fierro, Luis Molina (eds.), Los Almohades: Problemas y perspectivas, Consejo superior de investigaciones científicas, Madrid 2005, vol. II, (Estudios árabes e islámicos. Monografías, 11), p. 853-894.

7 See his contributions on the codicology of Arabic manuscripts in PAUL GéHIN (ed.), Lire le manuscrit médiéval: Observer et décrire, Colin, Paris 2005. He was, moreover, giving seminars on codicology both in France and in Lebanon.

8 See Marc Geoffroy, «Ibn Bājja, Abū Bakr ibn al-Sā'ig̀ (Avempace) », in Henrik LaGERLund (ed.), Encyclopedia of Medieval Philosophy. Philosophy between 500 and 1500, Springer, Dordrecht 2011, p. 483-486. Regarding his influence on Averroes's doctrine of the intellect (and Averroes's 
his use of Alexander of Aphrodisias in his theory of intellect (as indicated previously), but also presented as an important source for thinkers like Avempace and al-Bațalyūsi ${ }^{9}{ }^{9}$ was probably born in Fārāb, Turkestan, then moved to Baghdad, and afterwards to Syria, i.e. Aleppo and Damascus (where he died, maybe after having been for a while in Egypt as well). Also related to Baghdad were the translations of Aristoteles into Arabic, and this in its three major moments: the circle of al-Kindī, the translation school whose prominent figures were Hunayn Ibn Ishāa and Ishạa Ibn Ḥunayn, and the Peripatetic school of Baghdad (mid tenth/eleventh century). ${ }^{10}$ Quite naturally, besides Aristotle's name, those of other Greek thinkers, as e.g. Alexander of Aphrodisias and Themistius, appear many times in his publications. ${ }^{11}$ With them we find ourselves in Greece and Asia Minor, i.e. Paphlagonia and Constantinople (Themistius) and (perhaps) Cara, Anatolia (Alexander).

Finally, Marc's publications also offer a clear illustration of knowledge transfer from Late Antiquity to the Early Modern Period. As evidenced in what precedes, a first such transfer happened during the ninth till eleventh centuries, and went from Greece and Asia Minor to Baghdad, at that time the political and cultural capital of the Arabic-Islamic world; and a second covered the eleventh and twelfth centuries, passing from Baghdad to Muslim Andalusia. In an encyclopaedical article on the Latin translations of Ibn Rushd, Marc, however, mentions still another, third, transfer which was directed from Muslim Spain to the Christian Western world. ${ }^{12}$ In his article he makes clear that the translations

changing attitude toward Avempace), see e.g. ID., « L'Exposition de la Jonction de l'Intellect avec l'homme (ittișāl al-'aql bi-l-insān) d'Avempace dans le Compendium d'Averroès sur l'âme (Găwāmi ou Muhtașar al-nafs). Présentation et traduction annotée », in Nicole KoulayAn, MANSouR SAYAH (eds.), Synoptikos: Mélanges offerts à Dominique Urvoy, Presses Universitaires du Mirail, Toulouse 2011, p. 129-153; and ID., "Sources et origines de la théorie de l'intellect d'Averroès (I) », Mélanges de l'Université Saint-Joseph, 66 (2014-2015), p. 181-302.

9 See supra, fn. 3 (on Alexander's influence); fn. 8 (on Avempace); and ID., « al-Bațalyūsī, Abū Muhammad ibn al-Sīd», in LAGERLund (ed.), Encyclopedia of Medieval Philosophy, p. 148-149. Regarding Avempace and al-Bațalyūsī, one might also consult his « La formazione della cultura filosofica dell'Occidente musulmano ", in CRISTINA D'ANCONA (ed.), Storia della filosofia nell'Islam medievale, vol. II, Einaudi, Torino 2005, p. 671-722.

10 See ID., " Aristotle Arabic », in LAGERLUND (ed.), Encyclopedia of medieval philosophy, p. 105-116.

11 Regarding Alexander, see especially his «Alexandre d'Aphrodise et la doctrine de l'intellect d'Averroès: Remarques générales ", in Elisa CodA, CECILIA MarTini Bonadeo (eds.), De l'Antiquité tardive au Moyen Age: Études de logique aristotélicienne et de philosophie grecque, syriaque, arabe et latine offertes à Henri Hugonnard-Roche, Vrin, Paris 2014, p. 545-558 and ID., « La tradition arabe du

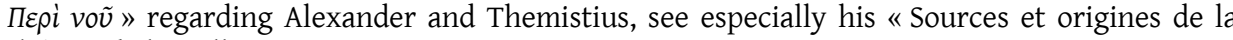
théorie de l'intellect».

12 See his "Ibn Rushd (Averroes), Latin Translations of ", in LAGERLund (ed.), Encyclopedia of medieval philosophy, p. 501-507. It is worthwhile to stress that Marc also points out, whenever relevant, the intermediary role played in this transfer process by Hebrew translations form Averroes's works. 
from Averroes's works into Latin were done for most part in mainland Italy (Bologna, Naples, Padua, Venice, Milan, Rome), but also in Sicily and Christian Spain, and encompass no less than four centuries (i.e. thirteenth-sixteenth centuries). So, one discovers in his studies three major moments of knowledge transfer between three major cultures, succeeding each other and spanning together no less than eight centuries.

I believe that this brief survey largely suffices to show how brilliant and allencompassing Marc's work was. His death is a tragic loss, not only for his family, for his friends (among whom I had the immense privilege to figure), but clearly for the scientific community at large. 